\title{
Antenna Design Considerations for High Specific Absorption Rate in Local Hyperthermia Treatment
}

\author{
Max Ammann \\ Technological University Dublin, max.ammann@tudublin.ie \\ Sergio Curto \\ Technological University Dublin, sergiocurtoramos@gmail.com \\ Xiulong Bao \\ Technological University Dublin, xiulong.bao@tudublin.ie
}

See next page for additional authors

Follow this and additional works at: https://arrow.tudublin.ie/engschececon

Part of the Electrical and Computer Engineering Commons

\section{Recommended Citation}

Ammann, M. et al. (2008) Antenna design considerations for high specific absorption rate in local hyperthermia treatment. IEEE International Symposium Antennas and Propagation Society, San Diego, California, 5-11 July, 2008, doi:10.1109/APS.2008.4619067

This Conference Paper is brought to you for free and open access by the School of Electrical and Electronic Engineering at ARROW@TU Dublin. It has been accepted for inclusion in Conference papers by an authorized administrator of ARROW@TU Dublin. For more information, please contact arrow.admin@tudublin.ie, aisling.coyne@tudublin.ie,gerard.connolly@tudublin.ie.

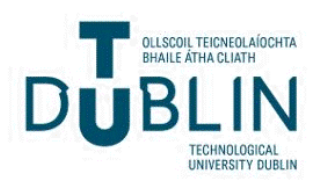




\section{Authors}

Max Ammann, Sergio Curto, Xiulong Bao, and Patrick McEvoy

This conference paper is available at ARROW@TU Dublin: https://arrow.tudublin.ie/engschececon/8 


\title{
Antenna Design Considerations for High Specific Absorption Rate in Local Hyperthermia Treatment
}

\author{
M. J. Ammann* ${ }^{(1,2)}$, S. Curto ${ }^{(1)}$, X. L. Bao ${ }^{(1,2)}$ and P. McEvoy ${ }^{(1)}$ \\ ${ }^{(1)}$ Antennas \& High Frequency Research Group \\ ${ }^{(2)}$ Centre for Telecommunications Value-chain Research (CTVR) \\ Dublin Institute of Technology, Kevin Street, Dublin 8, Ireland \\ Email Max.Ammann@,dit.ie
}

\begin{abstract}
Introduction
Clinical trials are being conducted across the world to determine the effectiveness of hyperthermia as a cancer therapy. It has been shown to be an effective treatment for some cancers in combination with radiotherapy, chemotherapy, or both [1-2]. The effectiveness of hyperthermia treatment is related to the temperature achieved during the treatment [1], which can be provided by ultrasound or microwave techniques. If microwaves are used, the effectiveness is related to the specific absorption ratio (SAR).

Both local hyperthermia and whole-body/regional hyperthermia are used to treat superficial or subcutaneous tumors and systemic/regional cancers, respectively. The main requirement for local hyperthermia is the delivery of electromagnetic energy from a small efficient applicator, which is placed in close proximity to the tumor area, sometimes using interstitial techniques/arrays [3].

An understanding of the antenna design, when in close proximity to human tissue leads to improved hyperthermia techniques. In order to prevent significant antenna detuning, and the consequent mismatch and reduced coupling to the body, the body proximity effects must be considered when designing the antenna. One method to achieve this is by optimizing the impedance matching when in proximity to the tissue. However, this method may suffer from reduced delivery when the antenna-to-tissue distance varies. These applicators may have efficient delivery only at a fixed distance and completely detune when the distance changes. An improved design method is to develop the antenna to have good impedance matching in the presence of tissue and also to have resilience to distance-dependent antenna detuning.

One of the frequencies used clinically is $434 \mathrm{MHz}$. It is a reasonably compromise between antenna size/efficiency and penetration depth. Resonant circular loops, dipoles and microstrip patches have been used for this purpose [4]. Resilience to detuning can be effected using methods such as stepped impedance matching, broadbanding and the use of geometries which enable mode alteration with change of distance. The other requirement is miniaturization, which is always a challenge for antenna designers. In this paper, the design of a miniaturized antenna which provides efficient deposition of energy and resilience to detuning is described.
\end{abstract}

\section{Antenna Design}

The basic element chosen is a microstrip patch antenna, but different miniaturization techniques have been used in the design of this applicator. The annular-ring geometry provides considerably smaller size geometry than the circular patch for the same operating frequency. The addition of groundplane slots and the concentric circular patch further miniaturises the element [5]. These techniques enable the antenna to be fabricated 
on a small $130 \mathrm{~mm} \times 130 \mathrm{~mm}$ groundplane. The laminate used is Taconic RF-35 of thickness $2.97 \mathrm{~mm}$ (relative permittivity 3.5 and loss tangent 0.0018 ). A short parametric study follows. In order to provide best matching and highest SAR, a planar 3-layered tissue model is employed [6-7] and shown in Figure 1. The model parameters are: Skin layer thickness, $S: 1.3 \mathrm{~mm}$, permittivity: 46.059 , conductivity: $0.702 \mathrm{~S} \mathrm{~m}^{-1}$, mass density: $1100 \mathrm{Kg} \mathrm{m}{ }^{-3}$; Fat Layer thickness, $F$ : $15 \mathrm{~mm}$, permittivity: 5.566, conductivity: $0.042 \mathrm{~S} \mathrm{~m}^{-1}$, mass density $916 \mathrm{Kg} \mathrm{m}^{-3}$; Muscle layer thickness, $M: 83.7 \mathrm{~mm}$, permittivity 56.865 , conductivity $0.805 \mathrm{~S} \mathrm{~m}^{-1}$, mass density $1041 \mathrm{Kg} \mathrm{m}^{-3}$. The proposed antenna is shown in Figure 2, and the optimized dimensions in body proximity are as follow: $\mathrm{L} 1=120 \mathrm{~mm}, \mathrm{~L} 2=114 \mathrm{~mm}, \mathrm{sw}=8.0 \mathrm{~mm}, \mathrm{SR}=12 \mathrm{~mm}, \mathrm{R} 1=62 \mathrm{~mm}, \mathrm{R} 2=51 \mathrm{~mm}$, $\mathrm{R} 3=38 \mathrm{~mm}$. Feed Point $(38 \mathrm{~mm}, 38 \mathrm{~mm})$, considering the centre of the circular patch as the rectangular coordinate system origin.

The cross slots in the groundplane, not only enable miniaturization, but also provide wide bandwidth and resilience to proximity detuning. Figure 3 illustrates that the slot width can be used to increase bandwidth and Figure 4 shows the S11 behavior as the distance antenna-tissue, $L$, varies. For the antenna in proximity to the layered model, $(\mathrm{L}=2.5 \mathrm{~mm})$, the return loss is better than $30 \mathrm{~dB}$ at $434 \mathrm{MHz}$ The $10 \mathrm{~dB}$ return loss bandwidth is about $84 \mathrm{MHz}$ from $387 \mathrm{MHz}$ to $471 \mathrm{MHz}$ and antenna has circular polarized characteristics as shown in Smith chart in Figure 5. The maximum SAR is $2.36 \mathrm{~W} / \mathrm{kg}$ averaged over $1 \mathrm{~g}$ of tissue volume. Figure 6, shows the SAR value at the different tissues interfaces and the maximum axial-ratio (AR) for the various antenna-tissue distances. It was seen that the polarisation is mainly circular when in close proximity to the model and becomes elliptical as the distance increases. Circular polarization (CP) performance corresponds with highest values of SAR.

\section{Conclusion}

The design of a miniaturised low-profile efficient hyperthermia applicator is presented. The efficiency is attributed to small size, resilience to detuning and wide bandwidth. The antenna provides a high value of SAR and is well matched to tissue, even at close distances.

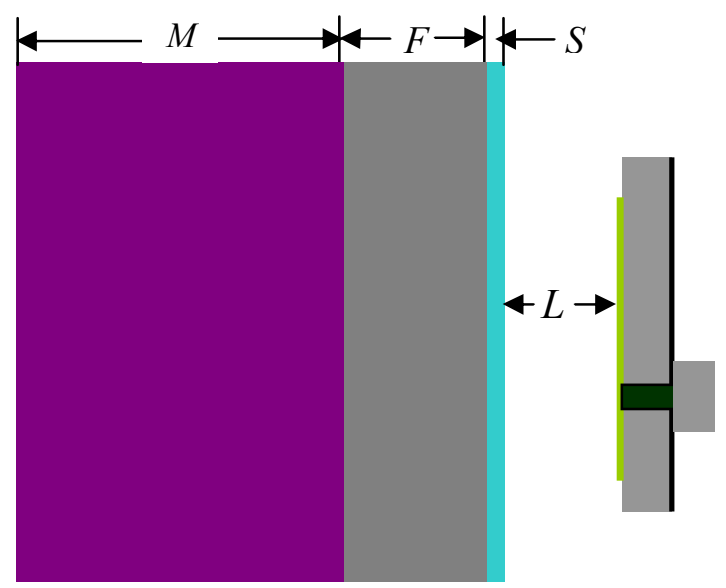

$(\mathrm{S}=1.3 \mathrm{~mm}, \mathrm{~F}=15 \mathrm{~mm}, \mathrm{M}=\mathbf{8 3 . 7} \mathrm{mm})$

Body Model

Antenna

Figure 1. Arrangement of antenna and 3-layered tissue model 

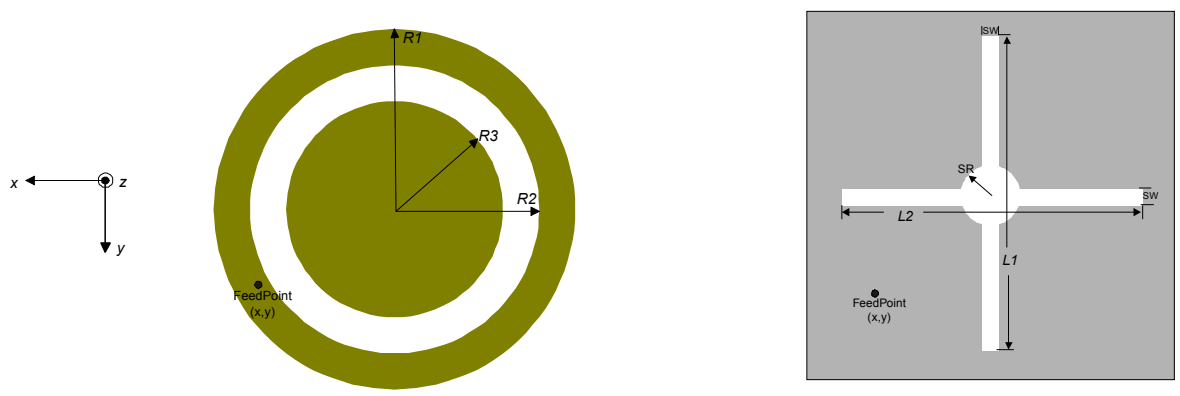

Figure 2. Geometry of the antenna showing annular patch and cross slot in groundplane.

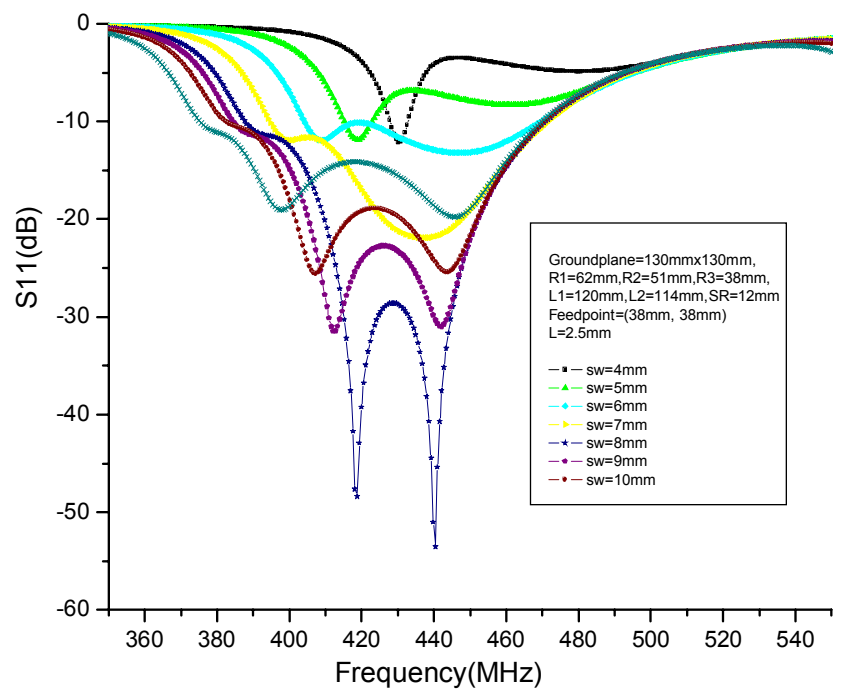

Figure 3. Simulated S11 for different slot widths $s w$ in the presence of 3-layer tissue model.

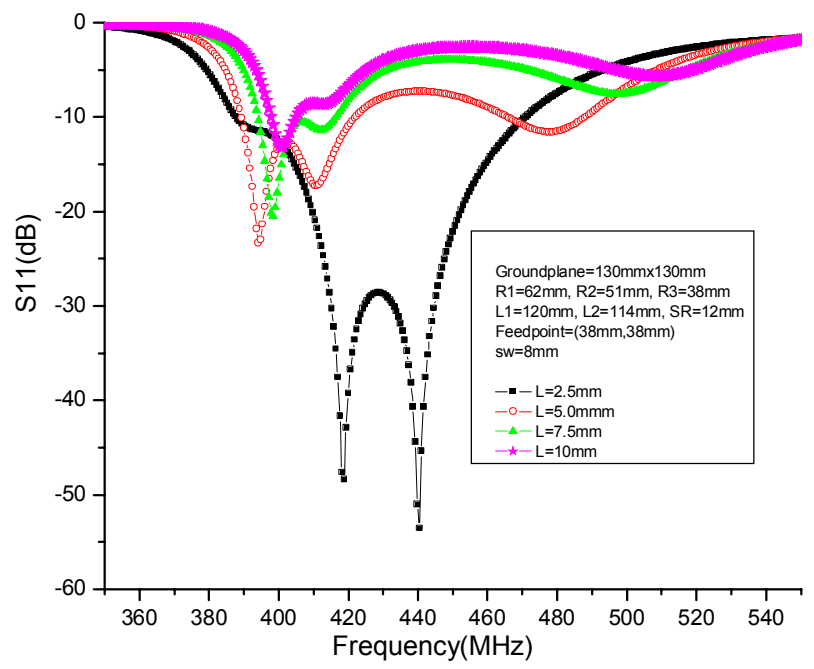

Figure 4. Simulated S11 for different distance between antenna and layered tissue model. 


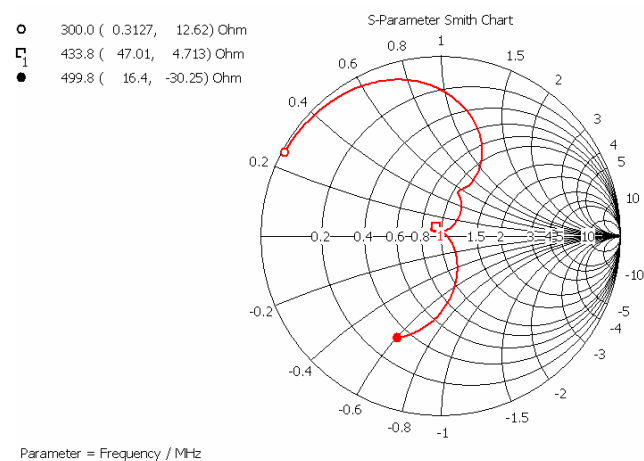

Figure 5. Simulated Smith chart showing CP for antenna at $2.5 \mathrm{~mm}$ from tissue

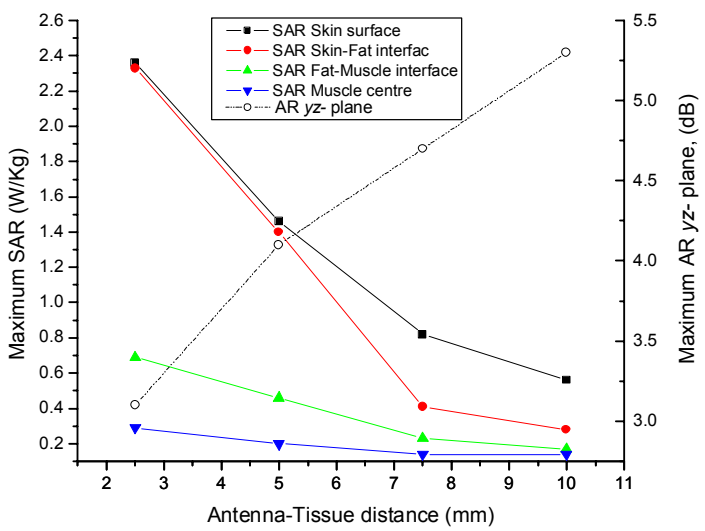

Figure 6. Maximum SAR and Axial-Ratio for different layer interfaces and distances

\section{References}

[1] J. Van der Zee, "Heating the patient: A promising approach?," Annals of Oncology 2002, 13, $1173-1184$.

[2] P. Wust P et al., "Hyperthermia in combined treatment of cancer," The Lancet Oncology, 2002, 3, 487-497.

[3] K. Saito, H. Yoshimura, K. Ito, Y. Aoyagi, H. Horita, "Clinical trials of interstitial microwave hyperthermia by use of coaxial-slot antenna with two slots," IEEE Trans., Microw. Theory \& Techniques, 2004, 52, (8), Part 2 , 1987-1991.

[4] S. Curto and M. J. Ammann, "Electromagnetic Interaction between Resonant Loop Antenna and Simulated Biological Tissue," Microwave and Opt. Techn. Lett., 2006, 48 (12), 24182421.

[5] X. L. Bao and M. J. Ammann, "Compact Annular-ring Embedded Circular Patch Antenna with a Cross-slot Ground Plane for Circular Polarization," Electronics Let., 2006, 42, (4), 192-193.

[6] A. Christ, T. Samaras, A. Kingenbock, and N. Kuster, "Characterization of the Electromagnetic Near-field Absorption in Layered Biological Tissue in the Frequency Range from $30 \mathrm{MHz}$ to 6000MHz," Phys. Med.Biol., 51, 2006, 4951-4965.

[7] S. Curto, and M. J. Ammann, "Electromagnetic Coupling Mechanism in a Layered Human Tissue Model as Reference for 434MHz RF Medical Therapy Applications," IEEE Antennas \& Propagat. Symp, 2007, 3185-3188.

This work was supported by Science Foundation Ireland and the Irish Research Council for Science, Engineering and Technology. 